\title{
Ethics of the Teaching Profession among Secondary School Teachers from School Leaders' Perspective in Riyadh
}

\author{
Huda Muttar Al-Hothali ${ }^{1}$ \\ ${ }^{1}$ Department of Educational Sciences, Prince Sattam Bin Abdulaziz University, Saudi Arabia \\ Correspondence: Huda Muttar Al-Hothali, Department of Educational Sciences, Prince Sattam Bin Abdulaziz \\ University, Saudi Arabia. E-mail: halhothali@gmail.com
}

Received: March 10, 2018

Accepted: May 30, $2018 \quad$ Online Published: August 28, 2018

doi:10.5539/ies.v11n9p47

URL: https://doi.org/10.5539/ies.v11n9p47

\begin{abstract}
The current study discusses the ethics of the teaching profession among secondary school teachers from school leaders' perspective in Riyadh. It aimed at providing a proposal for the ethics of the teaching profession. The study utilized the descriptive approach and a questionnaire applied to 426 school leaders. The sample responses means were moderate and high in the domain of teacher professional performance, and his relation to students, community, and school community as well as family. There were no statistically significant differences in the sample responses due to school type, age, years of experience, and qualification. The study recommended developing a code of ethics approved by the Ministry of Education and adopted by teachers, preparing rehabilitation training programs for teachers, designing a website of educational supervision and ethics of teaching, creating an atmosphere of mutual relations among teachers, educational supervisors, and school leaders.
\end{abstract}

Keywords: ethics, teaching profession, teachers, school leaders

\section{Introduction}

Education is perceived as the basic pillar of development and the teacher is the most important element of achieving social progress and preparing a generation with spiritual, ideological, emotional and moral values in the light of the goals and aspirations of the community. Capli (2015) explains that the role of the teacher has a moral dimension, since he/she is the link between the school and the society. He/she teaches and instructs students, organizes educational activities and cooperates with the family in raising children and cultivating morals in them. A teacher qualified with moral and scientific competences can create through his practices a new developed generation.

Based on the distinctive and serious role played by the teacher in the educational system, he/ she should have a set of characteristics commensurate with the roles assigned to him/ her. Ethics regulate the behavior of the professionals and preserve the continuity and survival of the profession (Deshach, 2014).

Studying teaching ethics is critical to the promotion of ethical practices reflected positively on the methodology of teaching, as well as on the relations between all elements of the school community. They are based largely on the availability of a positive trend towards the profession and represent a framework for the role of the teacher in the educational process (Forster, 2012).

Afifi (2005) shows that a code of ethics or rules of conduct imposed on the teacher in moral terms leaves a large space for the teacher's discretion, so he/ she decides what is moral or immoral under these rules. Improper implementation of these general rules empties them of their content and turns them into formal actions with no purpose.

Capli (2015) believes that the Code of Ethics of the Teaching profession is required for controlling the educational process and keeping it from deviation. Thus, the Code of Ethics represents a necessity for every professional and for educators specifically, because of the seriousness of their profession and its role in building the human personality with its various dimensions.

\subsection{Problem Statement}

It is noted that there are shortcomings in the commitment of some secondary school teachers to the ethics of the teaching profession. This may be due to the low level of self-control, the weakness of social relations within work 
environment, disloyalty to the profession, lack of knowledge of the code of ethics, as well as lack of interest in self-professional development (Al-Ghamdi \& Khalid, 2005; Kendrick, 2006; Jaballa, 2006; Alfalih, 2007).

In this context, the problem of study can be identified by the following major question: What are the ethics of the Teaching profession of secondary school teachers from the perspective of school leaders in Riyadh?

From this question, the following sub-questions are derived:

1) What is the importance of the teaching ethics among secondary school teachers from the perspective of school leaders in Riyadh?

2) What is the extent of practicing the teaching ethics among secondary school teachers from the perspective of the school leaders in Riyadh city?

3) What are the statistically significant differences among respondents on the realization of the importance and practice of the teaching ethics according to the study variables?

4) What is the suggested proposal for the teaching ethics?

\subsection{Objectives}

The study aimed to:

1) Recognize the importance of the teaching ethics from the sample's perspective.

2) Identify the extent of the practice of the teaching ethics by the sample.

3) Identify the statistically significant differences among respondents on the realization of the importance and practice of the teaching ethics according to the study variables.

4) Suggest a proposal for the ethics of teaching.

\subsection{Significance}

The current study is of significance due to the pivotal role of secondary school teachers in promoting the teaching ethics among students and improving the educational environment. It helps stand on the most important ethics of the teaching profession, which should be rooted in the teacher. It provides a proposal for the teaching code of ethics.

\subsection{Limitations}

Objective limits: The teaching ethics among secondary school teachers from school leaders' perspective.

Human limits: 426 school leaders.

Spatial limits: Schools of Riyadh city.

Temporal limits: The first semester of the academic year 2017/ 2018.

\subsection{Theoretical Framework}

Mansour and Talafh (2009) emphasize that ethical thinking is the ultimate goal that education seeks to achieve, as called by Simon "education as an ethical vision". Al-Zubi (2013) defines ethics as a charter that sets out the principles, values and duties to which teachers should adhere to perform their task in the best way possible. Education cannot function without values, because education is a moral process, as values shape educational action and direction. Mutraja (2004) has shown that values are critical for the educational process; values are the foundation through which the educational goals can be achieved. Professional ethics derive its importance from directing individual decisions and constituting the work basis approved by practitioners in the working environment. Accordingly, whoever violates them faces an embarrassing situation, fired or punished (Ajaji, 2012).

The teacher is responsible for social construction, achieving the goals of curricula, and representing a role model for students. The teacher is the backbone of the educational process through preparing the qualified manpower to meet the community needs, formulating the ideas of the youth, shaping their behavior and values and help them integrate into society Al-Mafda (2004). Accordingly, attention should be given to the moral aspect of the teacher, as the most important aspect of his/ her character, on which the professional ethics based. They are a set of rules and principals to which the teacher should commit. It helps him/ her achieve success in dealing with students, colleagues and society as well as in his profession (Loqmani, 2007). The degree to which the teacher belongs to his/ her profession is determined by his/ her commitment to the rules of that profession in all circumstances (Al-Khamees, 2013).

The teaching ethics are one of the inputs of the educational system that direct and regulate the behavior of educators by self-monitoring and providing them with referential frames to their work and emotional dimensions 
for their characters (Ajaji, 2012).

Al-Qarni (2008) asserts that absence of commitment to ethics and Islamic values in the profession of teaching has a negative impact on the educational environment. These include failure to invest courses in improving the ethical aspect of the learner, teacher's focus on giving information, lack of interest in a classroom environment characterized by cooperation and integration among the students in order to develop teamwork and encourage discussion, as well as lack of the teacher as an example. Al-Ghamdi (2006) and Al-Luqmani (2007) shows that the teacher's good characterizations have a morally positive impact on the student and the society. Such ethics include devotion, impartiality, continuity to deliver knowledge, conviction, job satisfaction, modesty and being a good example. These studies concluded that there is an urgent need for paying attention to the ethics of teaching profession in the educational process.

\subsection{Literature Review}

Nazzal (2001) aimed to identify the professional ethics of teaching in the light of Islamic thought, e.g. the teacher shall be an example, a giver for no interest, and consider individual differences. The study concluded that teachers' commitment to the professional ethics of teaching from the perspective of principals and supervisors was high and there were statistically significant differences due to educational qualification favoring the educationally qualified teachers. It recommended including professional ethics in the programs of preparing teachers, principals, and supervisor as well as including them as mandatory courses in colleges.

Anangisye (2010) aimed to identify the initiatives that enhance the professional ethics among teachers in teacher training colleges in a number of regions (Dar El-Salaam, Eringa and Tanzania in South Africa). Results showed that there are two main initiatives: the use of college bylaws and the teaching of moral rules of behavior. There are a range of challenges such as lack of courses on the professional ethics of teaching because of the inadequacy of teachers' trainers, lack of qualified teachers and lack of resources.

Boon (2011) aimed to identify the quality of the professional ethics of teaching among teachers. Results showed that there are no clear items related to the Ethics of teaching during the academic years of the bachelor's degree. The results highlighted the need of including professional ethics units to teachers' training courses.

Ibrahim (2012) aims to propose a code of ethics for the profession of teaching in Saudi Arabia. The study concluded the importance of the current code of ethics No. 221 for the ethics of the teaching profession in Saudi Arabia (i.e. a code that covers the responsibilities of the teacher towards the students, workmates, and country) from the perspective of teachers, principals and educational supervisors. There are statistically significant differences of the sample estimations of the importance of the current code of Ethics due to gender, current work, qualification, and years of experience.

Das (2014) aimed to identify the extent of the development of professional ethics of teaching through experience among female teachers in institutions of higher education in the state of Punjab. The experimental descriptive approach utilized, in addition to PEST-2007 to record the professional ethics of the teaching experience through observation. Results showed that only $9 \%$ of the teachers have a high level of professional ethics and $60 \%$ have an intermediate level of professional ethics, while $30.5 \%$ of the teachers showed a low level of professional ethics.

Nadia (2015) identified the importance of professional ethics for teachers in educational institutions in Nanigopal, Malo. Results showed that the professional ethics of teachers help increase people's knowledge of beliefs, values, ethics, learn the good and bad of them, and practice them to maximize their well-being and happiness.

Tabachnick et al. (2016) aimed to identify the ethics of teaching through beliefs and behaviors from the perspective of psychologists as educators. Results showed that the ethics of teaching include a set of behaviors and beliefs, such as course content, evaluation of students, educational environment, disrespectful behavior, research and publication issues, financial and material transactions, social relationships with students.

In the light of the literature review, it can be concluded that there is no previous Arabic study which covers the ethics of teaching profession among secondary school teachers from the perspective of school leaders in Riyadh. The current study aims at highlighting the importance of teaching professional ethics and presenting a proposal for a code of ethics for teaching.

Adherence to professional ethics contributes to controlling the expected behavior of all parties towards the profession in order to create the best moral environment that provides better learning and educational outputs. Capley (2015) points out that various countries have begun to draft codes of ethics for the teaching profession in order to achieve the desired objectives of the teaching profession. The Ministry of Education in Saudi Arabia has established the ethics of the teaching profession, issued in 1427 and circulated to all regions. They have been activated and adopted by every teacher (Al-Abboudi, 2010). 


\section{Ethics of the Teaching Profession}

Ethics of the teaching profession are a set of ethical rules and principles to which the teacher should adhere to preserve the high position of the profession in light of Saudi society, in general, and the educational institutions, in particular (Abu Tabikh, 2007). It can be summed up that ethics of the teaching profession are a set of rules, bases and starting points to which the secondary school teacher should adhere to achieve social and professional success and be able to gain the confidence of his students and colleagues.

\subsection{Challenges of Applying Professional Ethics}

According to Al-Roumi (2009), they include the deactivation of the punishment system; absence of role models; Absence of religious and national sense and favoring personal interests; and Absence of mutual understanding between officials and staff.

\subsection{Teaching Code of Ethics}

It is the sum of the good qualities and virtuous behaviors of public education staff (Ministry of Education, 2006). Ministry of Education in Saudi Arabia developed a teaching code of ethics by the Royal Decree No. 21 on 7/2/2006. It consisted of an introduction and 8 articles (Al-Qahtani, 2013). It aimed at raising the awareness of the teacher about the importance of the profession and its role in building the homeland future, enhancing the scientific and social status of the teacher, and encouraging the teacher to commit to professional ethics and values (Capley, 2015)

\subsection{Articles of General Teaching Code of Ethics in Saudi Education System}

The teaching code of ethics, as submitted by the Ministry of Education (2006), includes Article I: terms of Code, Article II: objectives of the Code and the rest of the articles are as follows:

Article III: Teaching Mission

1) Teaching is a mission which derives its ethics from Sharia guidance and the principles of our civilization, and demands its professionals to perform the right of belonging to it.

2) The teacher adopts a great mission, believes in its importance and performs its duties.

3) The teacher is proud of his profession, aware of his mission which require good reputation and purity of the heart, and able to preserve the honor of the teaching profession.

Article IV: Professional performance of the teacher

1) The teacher is a Muslim proud of his/ her religion, follower of the Prophet (PBUH) in all his sayings, and moderate in his/ her dealings and judgments.

2) The teacher understands that professional development is a basic duty and continuous self-education is a life style through developing his/ her knowledge in Domain of specialization and teaching skills.

3) The teacher is aware that integrity, honesty, patience, firmness, discipline, tolerance, good-looking and smiling face are key features of his/ her personality.

4) The teacher realizes that conscience and critical sense is the real monitor on his/ her behavior and he/ she, as a role model, seeks to disseminate this spirit among students and society.

5) The teacher contributes to consolidating the concept of citizenship, cultivating the principles of moderation, tolerance and coexistence and rejecting extremism among students.

Article V: teacher and students

1) The relationship between the teacher and his/ her students is based on the teacher's desire to educate and help them, guarded by the necessary firmness, and aims to achieve build the desired generation for the nation development and progress.

2) The teacher is the role model not only for students, but for the society. $\mathrm{He} /$ she is keen on having a lasting benign impact on people, so he/ she upholds moral values and ideals and disseminates them among students and society members.

3) The teacher believes in the good intention of students and teaches them to adopt the principle of good intention in their public and private life and to provide excuse for others and perceive their own flaws.

4) Teacher to make sure that the benefit of his students is making all his efforts in education and education and guidance guide them on the path of good and desire them and shows them evil and provide them in the integrated care of their development religiously, morally, psychologically, socially and health. 
5) The teacher is fair while dealing with, monitoring and evaluating the performance of the students. He/ she protect their dignity, preserves their rights, and invest their time through introducing useful lessons in his/ her specialization.

6) The teacher is a model of practicing wisdom and kindness who avoids violence and forbids it. He/ she encourage students to sound thinking, constructive dialogue, good listening to others' opinions, tolerance with people and disseminating the principal of Shura.

7) The teacher avoids using physical and psychological punishment to students.

8) The teacher seeks to provide the student with the mental and scientific skills that develop his critical scientific thinking and continuous self-education.

Article VI: Teacher and Society

1) The teacher enhances students' sense of belongingness to their religion and country and the importance of positive interaction with other cultures.

2) The teacher is faithful to the nation unity and solidarity. He works hard to disseminate the values of cooperation and love among all citizens to achieve security, stability and development.

3) The teacher is valued, respected and trusted by the society. He/she works hard to be worthy of this trust and appreciation.

4) The teacher is an influential society member, since he is entrusted with achieving knowledge progress, scientific advancement, intellectual creativity, cultural contribution and dissemination of morals among students.

5) The teacher represents an honest image of the educated person belonging to his religion and his country. Accordingly, he has to expand his culture and information resources so as to be able to form a mature opinion based on science, knowledge and vast experience to help students construct their own vision and consider different points of views as the basic cultural components of building human civilization.

Article VII: Teacher and school community

1) Mutual trust and teamwork spirit are the basis of the relationship between the teacher and his colleagues and between teachers and educational management.

2) The teacher understands that respecting professional conduct rules, adherence to regulations and instructions, and positive participation in the school activities are essential elements in achieving the goals of the educational institution.

Article VIII: Teacher and Family

1) The teacher is the partner of the parents in upbringing the student, so he/ she is keen on strengthening the bonds of trust between home and school.

2) Educational professionals carry out their duties and follow the principles embodied in these ethics and endeavor to disseminate and consolidate them among their colleagues and in society in general.

Justifications for selecting this Code of ethics:

1) Its easy items and few pages which do not exceed (15) pages.

2) It has been publicized in all Saudi schools and teachers required to commit to it.

3) It is consistent with the directives of the Ministry of activating it in Domain of education.

4) Its provisions include all aspects of the desired personality of the ideal teacher.

5) It contains thirty educational values capable of bringing out a good generation (Qarni, 2008).

\subsection{Deficits of the Teaching Code of Ethics}

The introduction to the Code of ethics is figurative without any practical idea or logical sequence of sentences. With reference to terminology, teacher, student, and ethics are not well defined. The code includes morals that represent relatively constant values such as honesty and loyalty. On the contrary, it overlooked basic professional ethics such as teaching methods and learning techniques (Al-Hujilan, 2007).

\section{Methodology and Procedures}

Population and sampling

Population: All secondary school leaders in Riyadh. 
Sample: 426 school leaders.

Tool: A questionnaire to measure the importance and practice of the professional ethics of teaching among secondary school teachers from school leaders' perspectives, including five domains: Teacher professional performance, teacher and students, teacher and community, teacher and school community, and teacher and family.

\section{Results and Discussion}

To answer the question, what is the importance of secondary school teacher's professional performance from the perspective of school leaders in Riyadh? Means and standard deviations were computed, as shown in Table 1.

Table 1. The importance of secondary school teacher's professional performance

\begin{tabular}{|c|c|c|c|c|c|}
\hline No. & Item & Mean & $\begin{array}{l}\text { Standard } \\
\text { Deviation }\end{array}$ & Rank & $\begin{array}{c}\text { Application } \\
\text { degree }\end{array}$ \\
\hline 13 & The teacher has an awakening conscience that monitors her performance. & 4.29 & 0.47 & 1 & High \\
\hline 7 & The teacher keeps her promises inside the school. & 4.22 & 0.69 & 2 & High \\
\hline 16 & The teacher shows a smiling-face during performing work. & 4.11 & 0.57 & 3 & High \\
\hline 14 & $\begin{array}{l}\text { The teacher contributes to enhancing citizenship and belonging among } \\
\text { students. }\end{array}$ & 4.03 & 0.60 & 4 & High \\
\hline 4 & The teacher seeks to achieve a high degree of professional development. & 3.99 & 0.51 & 5 & High \\
\hline 1 & The teacher is committed to moderate judgments & 3.91 & 0.53 & 6 & High \\
\hline 6 & The teacher is keen on performing work as perfect as possible & 3.82 & 0.49 & 7 & High \\
\hline 15 & The teacher has a good looking inside the school & 3.80 & 0.74 & 8 & High \\
\hline 3 & The teacher respects and complies with the Code of Conduct & 3.70 & 0.64 & 9 & High \\
\hline 9 & The teacher acts honestly inside the school & 3.56 & 0.61 & 10 & Moderate \\
\hline 2 & The teacher is committed to moderate dealings & 3.33 & 0.50 & 11 & Moderate \\
\hline 5 & $\begin{array}{l}\text { The teacher complies with the regulations and instructions issued by school } \\
\text { officials }\end{array}$ & 3.28 & 0.73 & 12 & Moderate \\
\hline 10 & The teacher commits to discipline and integrity inside the school & 3.25 & 0.66 & 13 & Moderate \\
\hline 12 & The teacher uses good expressions and phrases inside the school & 3.12 & 0.58 & 14 & Moderate \\
\hline 8 & The teacher acts honestly inside the school & 3.05 & 0.80 & 15 & Moderate \\
\hline \multirow[t]{2}{*}{11} & $\begin{array}{l}\text { The teacher contributes to cultivating the principle of moderation, tolerance } \\
\text { and coexistence among students }\end{array}$ & 2.94 & 0.79 & 16 & Moderate \\
\hline & Overall performance & 3.65 & 0.58 & 16 & Moderate \\
\hline
\end{tabular}

Table 1 shows that the means of the sample responses to the domain of teacher professional performance are high and moderate. Item (3) obtained the first rank with a high degree of practice. It may be attributed to the teacher realization that conscience is the real monitor on her performance, so she, as a role model, works hard to spread this spirit among students and community members. This result is inconsistent with Cevat (2002), Anangisye (2010), Das (2014), Gluchmanova (2015) and Tabachnick et al. (2016).

Item (11) got the last rank and a moderate degree of practice. It may attributed to the teacher's underestimation of the importance of consolidating the concept of citizenship among students as well as having insufficient training courses to raise awareness about the danger of extremist ideology and its effects on students. This result is inconsistent with Nadia (2015) and Anangisye (2010).

To answer the question, what is the degree of practicing professional performance among secondary school teachers from school leaders' perspective in Riyadh? The mean and standard deviations were obtained as shown in Table 2. 
Table 2. Degree of professional performance practice among secondary school teachers

\begin{tabular}{|c|c|c|c|c|c|}
\hline No. & Item & Mean & $\begin{array}{l}\text { Standard } \\
\text { Deviation }\end{array}$ & Rank & $\begin{array}{l}\text { Practice } \\
\text { degree }\end{array}$ \\
\hline 13 & $\begin{array}{l}\text { The teacher complies with the regulations and instructions issued by school } \\
\text { officials }\end{array}$ & 4.29 & 0.47 & 1 & High \\
\hline 15 & The teacher has a good looking inside school. & 4.20 & 0.58 & 2 & High \\
\hline 16 & The teacher shows a smiling-face during performing work & 4.11 & 0.50 & 3 & High \\
\hline 14 & The teacher contributes to enhancing citizenship and belonging among students. & 4.03 & 0.60 & 4 & High \\
\hline 4 & The teacher seeks to achieve a high degree of professional development. & 3.99 & 0.51 & 5 & High \\
\hline 1 & The teacher is committed to moderate judgments & 3.91 & 0.52 & 6 & High \\
\hline 6 & The teacher is keen on performing work as perfect as possible & 3.82 & 0.54 & 7 & High \\
\hline 7 & The teacher keeps her promises inside the school & 3.72 & 0.74 & 8 & High \\
\hline 3 & The teacher respects and complies with the Code of Conduct & 3.70 & 0.64 & 9 & High \\
\hline 9 & The teacher acts honestly inside the school & 3.56 & 0.63 & 10 & Moderate \\
\hline 2 & The teacher is committed to moderate dealings & 3.33 & 0.52 & 11 & Moderate \\
\hline 5 & $\begin{array}{l}\text { The teacher complies with the regulations and instructions issued by school } \\
\text { officials }\end{array}$ & 3.28 & 0.73 & 12 & Moderate \\
\hline 10 & The teacher commits to discipline and integrity inside the school & 3.25 & 0.66 & 13 & Moderate \\
\hline 8 & The teacher acts honestly inside the school & 3.20 & 0.54 & 14 & Moderate \\
\hline 12 & The teacher uses good expressions and phrases inside the school & 3.07 & 0.59 & 15 & Moderate \\
\hline \multirow[t]{2}{*}{11} & $\begin{array}{l}\text { The teacher contributes to cultivating the principle of moderation, tolerance and } \\
\text { coexistence among students }\end{array}$ & 2.94 & 0.76 & 16 & Moderate \\
\hline & Total performance & 3.65 & 0.56 & 16 & Moderate \\
\hline
\end{tabular}

Table 2 shows that the means of the sample responses to the items of the degree of practicing professional performance among secondary school teachers are high and moderate. Item 13 achieved the first rank with a high degree of practice. It may be attributed to the teacher's awareness that commitment to regulations and instructions contributes to achieving the desired educational objectives. This result is consistent with Gluchmanova (2015) which showed that teachers should adhere to the professional rules and keep their promises to students.

Item (11) got the last rank with a moderate application degree. It may be attributed to lack of training courses and workshops held by the Ministry of Education and school administrations that provide teachers with opportunities for professional development as a result of not believing in the usefulness of these courses. This result is inconsistent with Boon (2011) which emphasized the need to hold training courses for teachers, including modules of professional ethics and ethical practices in the classroom.

To answer the question, what is the importance of the relationship between secondary school teacher and students from school leaders' perspective in Riyadh? The mean and standard deviations were obtained as shown in Table 3.

Table 3. Importance of relation between secondary school teacher and students

\begin{tabular}{|c|c|c|c|c|c|}
\hline No. & Item & Mean & $\begin{array}{l}\text { Standard } \\
\text { Deviation }\end{array}$ & Rank & $\begin{array}{l}\text { Practice } \\
\text { degree }\end{array}$ \\
\hline 7 & The teacher is fair with students. & 4.14 & 0.48 & 1 & High \\
\hline 9 & The teacher avoids ridicule and mockery with her students. & 4.06 & 0.47 & 2 & High \\
\hline 3 & The teacher encourages constructive dialogue. & 3.95 & 0.50 & 3 & High \\
\hline 10 & $\begin{array}{l}\text { The teacher accepts students with different social, economic and religious } \\
\text { backgrounds. }\end{array}$ & 3.90 & 0.63 & 4 & High \\
\hline 15 & The teacher characterized by decisive and moderate dealings with students. & 3.86 & 0.59 & 5 & High \\
\hline 13 & $\begin{array}{l}\text { The teacher seeks to provide students with mental and scientific skills that } \\
\text { develop their critical scientific thinking. }\end{array}$ & 3.84 & 0.55 & 6 & High \\
\hline 2 & The teacher is keen on benefiting students. & 3.84 & 0.67 & 7 & High \\
\hline 6 & The teacher students' relationship is based on good intention. & 3.71 & 0.60 & 8 & High \\
\hline 11 & The teacher is tolerant during situations of disagreement & 3.60 & 0.58 & 9 & High \\
\hline 14 & The teacher seeks to provide students with continuous self-education skills & 3.60 & 0.66 & 10 & Moderate \\
\hline 5 & The teacher is keen on spreading the principle of Shura. & 3.49 & 0.79 & 11 & Moderate \\
\hline 1 & The teacher is a role model for students. & 3.43 & 0.64 & 12 & Moderate \\
\hline
\end{tabular}




\begin{tabular}{llrrr}
\hline & The teacher is committed to objectivity and comprehensiveness during the & 3.21 & 0.70 & 13 \\
& evaluation process. & 3.00 & 0.72 \\
4 & The teacher enhances good listening skills among students. & 2.99 & 0.84 & 14 \\
8 & The teacher avoids imposing physical and psychological punishment. & 3.64 & 0.61 & 15 \\
& Total performance & Moderate & Moderate \\
\hline
\end{tabular}

Table 3 shows that the means of the sample responses to the domain of teacher and students (in terms of importance) are high and moderate. Item (7) achieved the first rank with (4.14) mean. It may be attributed to the teacher's keenness to enhance the principle of justice among students. The teacher's fair behavior, as a role model, will be reflected positively on students' behavior. On the contrary, absence of justice in the classroom leads to tension, hatred and incompatibility between teacher and students. This result is inconsistent with Cevat (2002), Anangisye (2010), Das (2014), Gluchmanova (2015) and Tabachnick et al. (2016).

Item (8) got the last rank with a Moderate degree of practice. This result is due to the awareness of secondary school teachers that harmful punishment is against professional ethics, forbidden by the instructions of the Ministry of Education, leads to lack of respect between the teacher and the student and reflected negatively on the students' achievement. This result is inconsistent with Covat (2002), Anangisye (2010), Das (2014), Gluchmanova (2015) and Tabachnick et al. (2016).

To answer the question, what is the degree of practicing professional relationship between secondary school teacher and students from school leaders' perspective in Riyadh? The mean and standard deviations obtained as shown in Table 4.

Table 4. The degree of practicing professional relationship between secondary school teacher and students

\begin{tabular}{|c|c|c|c|c|c|}
\hline No. & Item & Mean & $\begin{array}{l}\text { Standard } \\
\text { Deviation }\end{array}$ & Rank & $\begin{array}{l}\text { Degree of } \\
\text { practice }\end{array}$ \\
\hline 10 & $\begin{array}{l}\text { The teacher accepts students with different social, economic and religious } \\
\text { backgrounds }\end{array}$ & 4.00 & 0.58 & 1 & High \\
\hline 6 & The teacher students' relationship is based on good intention. & 3.96 & 0.50 & 2 & High \\
\hline 3 & The teacher encourages constructive dialogue & 3.95 & 0.60 & 3 & High \\
\hline 14 & The teacher seeks to provide students with continuous self-education skills & 3.84 & 0.61 & 4 & High \\
\hline 15 & The teacher characterized by decisive and moderate dealings with students. & 3.82 & 0.57 & 5 & High \\
\hline 13 & $\begin{array}{l}\text { The teacher seeks to provide students with mental and scientific skills that } \\
\text { develop their critical scientific thinking. }\end{array}$ & 3.82 & 0.56 & 6 & High \\
\hline 12 & $\begin{array}{l}\text { The teacher is committed to objectivity and comprehensiveness during the } \\
\text { evaluation process. }\end{array}$ & 3.77 & 0.60 & 7 & High \\
\hline 9 & The teacher avoids ridicule and mockery with her students & 3.66 & 0.58 & 8 & High \\
\hline 11 & The teacher is tolerant during situations of disagreement & 3.50 & 0.65 & 9 & High \\
\hline 7 & $\begin{array}{l}\text { The teacher accepts students with different social, economic and religious } \\
\text { backgrounds. }\end{array}$ & 3.41 & 0.69 & 10 & Moderate \\
\hline 4 & The teacher enhances good listening skills among students. & 3.39 & 0.75 & 11 & Moderate \\
\hline 1 & The teacher is a role model for students & 3.22 & 0.71 & 12 & Moderate \\
\hline 2 & The teacher is keen on benefiting students & 3.05 & 0.80 & 13 & Moderate \\
\hline 5 & The teacher is keen on spreading the principle of Shura & 2.85 & 0.67 & 14 & Moderate \\
\hline \multirow[t]{2}{*}{8} & The teacher avoids imposing physical and psychological punishment & 2.72 & 0.82 & 15 & Moderate \\
\hline & Total performance & 3.64 & 0.63 & & Moderate \\
\hline
\end{tabular}

Table 4 shows that the means of the sample responses to the domain of teacher and students (in terms of practice) are high and moderate. Item (10) achieved the first rank with a high degree of practice. It may be attributed to the teacher's keenness, as a role model, on achieving the principle of justice among students which will be reflected positively on their relation. On the contrary, absence of justice in the classroom leads to tension, hatred and incompatibility between teacher and students. This result is inconsistent with Covat (2002), Anangisye (2010), Das (2014), Gluchmanova (2015) and Tabachnick et al. (2016).

Item (8) obtained the last rank with a moderate degree of practice. Because the teacher believes that harmful punishment is inconsistent with the ethics of the teaching profession. 
To answer the question, what is the importance of the relation between secondary school teacher and community from school leaders' perspective in Riyadh? The mean and standard deviations computed as shown in Table 5.

Table 5. Importance of the relation between secondary school teacher and community

\begin{tabular}{|c|c|c|c|c|c|}
\hline No. & Item & Mean & $\begin{array}{c}\text { Standard } \\
\text { Deviation }\end{array}$ & Rank & $\begin{array}{c}\text { Practice } \\
\text { degree }\end{array}$ \\
\hline 8 & $\begin{array}{l}\text { The teacher is keen on playing a role in cognitive, scientific, intellectual and } \\
\text { cultural advancement of society. }\end{array}$ & 3.97 & 0.68 & 1 & High \\
\hline 5 & The teacher is keen on acquiring the trust and respect of the community. & 3.90 & 0.60 & 2 & High \\
\hline 11 & The teacher cares for raising cultural awareness among community members. & 3.80 & 0.59 & 3 & High \\
\hline 4 & The teacher seeks to teach students the value of homeland security and stability. & 3.78 & 0.68 & 4 & High \\
\hline 7 & $\begin{array}{l}\text { The teacher is keen on playing a role in knowledge, scientific, intellectual and } \\
\text { cultural advancement of society. }\end{array}$ & 3.67 & 0.71 & 5 & High \\
\hline 9 & $\begin{array}{l}\text { The teacher is keen on expanding the scope of her education and information } \\
\text { resources }\end{array}$ & 3.67 & 0.74 & 6 & High \\
\hline 1 & The teacher encourages students to be influential society members. & 3.59 & 0.63 & 7 & Moderate \\
\hline 3 & $\begin{array}{l}\text { The teacher seeks to develop the importance of positive interaction with students } \\
\text { of various cultures. }\end{array}$ & 3.53 & 0.75 & 8 & Moderate \\
\hline 10 & The teacher cares for raising health awareness among community members. & 3.44 & 0.80 & 9 & Moderate \\
\hline 12 & The teacher encourages students to be influential members of society. & 3.21 & 0.78 & 10 & Moderate \\
\hline 2 & $\begin{array}{l}\text { The teacher is keen on cultivating the values of sincere respect and obedience to } \\
\text { the guardian among students. }\end{array}$ & 3.18 & 0.83 & 11 & Moderate \\
\hline \multirow[t]{2}{*}{6} & The teacher cares for raising religious awareness among community members. & 3.06 & 0.70 & 12 & Moderate \\
\hline & Total performance & 3.57 & 0.66 & 12 & Moderate \\
\hline
\end{tabular}

Table 5 shows that the mean for domain of teacher and community (in terms of importance) were high and moderate. Item (8) achieved the first rank with a high degree of practice. It may be attributed to the fact that the school is an integral part of the local community. The teacher morality contributes to the development of the society and affects the family and the students.

Item (6) got the last rank with a moderate degree of practice. It may be attributed to the fact that the principal is responsible for establishing relations with the community, as a part of her duties. This result is inconsistent with Covat (2002), Anangisye (2010), Das (2014), Gluchmanova (2015) and Tabachnick et al. (2016).

To answer the question, what is the degree of practicing professional relationship between secondary school teacher and community from the perspective of school leaders in Riyadh? The mean and standard deviations were obtained as shown in Table 6 .

Table 6. The degree of practicing professional relationship between secondary school teacher and community

\begin{tabular}{|c|c|c|c|c|c|}
\hline No. & Item & Mean & $\begin{array}{l}\text { Standard } \\
\text { Deviation }\end{array}$ & Rank & $\begin{array}{c}\text { Practice } \\
\text { degree }\end{array}$ \\
\hline 8 & $\begin{array}{l}\text { The teacher is keen on playing a role in cognitive, scientific, intellectual and } \\
\text { cultural advancement of society. }\end{array}$ & 3.97 & 0.68 & 1 & High \\
\hline 5 & The teacher is keen on acquiring the trust and respect of the community. & 3.85 & 0.63 & 2 & High \\
\hline 11 & The teacher cares for raising cultural awareness among community members. & 3.80 & 0.59 & 3 & High \\
\hline 4 & The teacher seeks to teach students the value of homeland security and stability. & 3.78 & 0.68 & 4 & High \\
\hline 7 & The teacher keeps active communication with community members. & 3.70 & 0.67 & 5 & High \\
\hline 9 & $\begin{array}{l}\text { The teacher is keen on expanding the scope of her education and information } \\
\text { resources }\end{array}$ & 3.67 & 0.74 & 6 & High \\
\hline 1 & The teacher develops relationships with local institutions in favor of the school. & 3.59 & 0.63 & 7 & Moderate \\
\hline 3 & $\begin{array}{l}\text { The teacher seeks to develop the importance of positive interaction with students } \\
\text { of various cultures. }\end{array}$ & 3.53 & 0.75 & 8 & Moderate \\
\hline 10 & The teacher cares for raising health awareness among community members. & 3.44 & 0.80 & 9 & Moderate \\
\hline 12 & The teacher encourages students to be influential members of society. & 3.21 & 0.78 & 10 & Moderate \\
\hline
\end{tabular}




\begin{tabular}{llrr}
\hline & The teacher is keen on cultivating the values of sincere respect and obedience to & 3.16 & 0.80 \\
the guardian among students. & 3.09 & 0.65 \\
6 & The teacher cares for raising religious awareness among community members. & 3.57 & 0.65 \\
Total performance & Moderate & 12 \\
\hline
\end{tabular}

Table 6 shows that the mean the domain of teacher and community (in terms of practice) were high and moderate. Item (8) achieved the first rank with a high degree of practice. It may be attributed to the adequacy of the courses organized by the Ministry of Education for teachers. This result is consistent with Gluchmanova (2015) which argued that teachers should guarantee providing scientific, intellectual, and moral progress for students and showing them the due respect and esteem.

Item (6) got the last rank with a moderate degree of practice. It may be attributed to that religious awareness is related to Islamic Education and the teacher adheres to the items of the curriculum.

To answer the question, what is the importance of the relation between secondary school teacher and school community from school leaders perspective in Riyadh? The mean and standard deviations were calculated as indicated in Table 7.

Table 7. Importance of the relation between secondary school teacher and school community

\begin{tabular}{llcccc}
\hline No. & Item & Mean & Standard Deviation & Rank & Practice degree \\
\hline 3 & Relation between teacher and school community based on mutual trust. & 4.45 & 0.34 & 1 & High \\
1 & The teacher provides advice for the development of school work. & 4.33 & 0.50 & 2 & High \\
9 & The teacher keeps her temper while discussing officials. & 4.18 & 0.49 & 3 & High \\
6 & The teacher praises students when they do charity work inside the school. & 4.02 & 0.60 & 4 & High \\
2 & The teacher adopts team spirit in school community. & 3.89 & 0.52 & 5 & High \\
11 & The teacher is committed to positive participation in school activities. & 3.82 & 0.48 & 6 & High \\
7 & The teacher provides professional assistance to her colleagues. & 3.76 & 0.59 & 7 & Moderate \\
8 & The teacher commits to her appointments with officials & 3.70 & 0.67 & 8 & Moderate \\
4 & The teacher is modest when she is at school. & 3.62 & 0.63 & 9 & Moderate \\
10 & The teacher treats her colleagues and officials with due respect. & 3.51 & 0.56 & 10 & Moderate \\
5 & The teacher keeps friendly relationships within the school. & 3.40 & 0.69 & 11 & Moderate \\
& Total performance & 3.88 & 0.50 & 11 & Moderate \\
\hline
\end{tabular}

Table 7 shows that the mean for the domain of teacher and school community (in terms of importance) were high and moderate. Item (3) achieved the first rank with a high degree of practice. It may be attributed to confidence between the teacher and the community result in a healthy school environment that enables development and progress. This result is inconsistent with Covat (2002), Anangisye (2010), Das (2014), Gluchmanova (2015) and Tabachnick et al. (2016).

Item (6) got the last rank with a moderate degree of practice. It may be attributed to relationship based on respect and understanding, as stipulated in the Teaching Code of Ethics. It is inconsistent with Gluchmanova (2015) which emphasized that teachers respect students' dignity in a way that they fulfill their professional commitment.

To answer the question, what is the degree of practicing professional relationship between secondary school teacher and school community from the perspective of school leaders in Riyadh? The mean and standard deviations were obtained as shown in Table 8. 
Table 8 . The degree of practicing professional relationship between secondary school teacher and school community

\begin{tabular}{llcccc}
\hline No. & Item & Mean & Standard Deviation & Rank & Practice degree \\
\hline 1 & The teacher provides advice for the development of school work. & 4.40 & 0.38 & 1 & High \\
3 & Relation between teacher and school community based on mutual trust. & 4.29 & 0.50 & 2 & High \\
9 & The teacher keeps her temper while discussing officials. & 4.15 & 0.52 & 3 & High \\
6 & The teacher praises students when they do charity work inside the school. & 4.05 & 0.60 & 4 & High \\
2 & The teacher adopts team spirit in school community. & 3.89 & 0.52 & 5 & High \\
11 & The teacher is committed to positive participation in school activities. & 3.80 & 0.48 & 6 & High \\
7 & The teacher provides professional assistance to her colleagues. & 3.70 & 0.59 & 7 & High \\
8 & The teacher commits to her appointments with officials & 3.70 & 0.67 & 8 & High \\
4 & The teacher is modest when she is at school. & 3.64 & 0.64 & 9 & Moderate \\
10 & The teacher treats her colleagues and officials with due respect. & 3.51 & 0.56 & 10 & Moderate \\
5 & The teacher keeps friendly relationships within the school. & 3.40 & 0.69 & 11 & Moderate \\
& Total performance & 3.87 & 0.52 & 11 & Moderate \\
\hline
\end{tabular}

Table 8 shows that the mean for the domain of teacher and school community (in terms of practice) were high and moderate. Item (1) obtained the first rank with a high degree of practice. It may be attributed to that the teacher is responsible for developing the school in the light of the latest technological developments and encouraging the progress of the school. This result is consistent with Gluchmanova (2015) which emphasized that teachers respect students' dignity in a way that they fulfill their professional commitment; for example, to provide details of their studies, assessment criteria, course schedules, lectures and seminars and to provide students with assistance or advice.

Item (6) got the last rank with a moderate degree of practice. It may be attributed to the crowded schedule of the teacher and the lack of a suitable way to activate channels of communication among teachers which have a negative impact on establishing friendly relations within the school.

To answer the question, what is the importance of the relation between secondary school teacher and family from school leaders' perspective in Riyadh? The mean and standard deviations were calculated as indicated in Table 9.

Table 9. Importance of the relation between secondary school teacher and family

\begin{tabular}{|c|c|c|c|c|c|}
\hline No. & Item & Mean & $\begin{array}{l}\text { Standard } \\
\text { Deviation }\end{array}$ & Rank & $\begin{array}{l}\text { Practice } \\
\text { degree }\end{array}$ \\
\hline 9 & The teacher keeps the secrets of parents. & 4.01 & 0.69 & 1 & High \\
\hline 10 & $\begin{array}{l}\text { The teacher is keen on benefiting from distinguished family members in } \\
\text { developing school work. }\end{array}$ & 3.89 & 0.50 & 2 & High \\
\hline 2 & The teacher calls parents to participate in various events. & 3.83 & 0.57 & 3 & High \\
\hline 6 & The teacher kindly listens to the family's observations about her performance. & 3.77 & 0.49 & 4 & High \\
\hline 4 & The family participates in decisions concerning their daughters. & 3.69 & 0.53 & 5 & High \\
\hline 1 & The teacher is keen on enhancing trust between family and school. & 3.68 & 0.68 & 6 & High \\
\hline 7 & $\begin{array}{l}\text { The teacher cooperates with the family in solving the problems of their } \\
\text { daughters. }\end{array}$ & 3.59 & 0.63 & 7 & Moderate \\
\hline 3 & $\begin{array}{l}\text { The teacher calls on parents to participate continuously and actively in the } \\
\text { activities of the school. }\end{array}$ & 3.56 & 0.54 & 8 & Moderate \\
\hline 5 & The teacher reports the family on the academic level of their daughters. & 3.40 & 0.70 & 9 & Moderate \\
\hline \multirow[t]{2}{*}{8} & The teacher consults the family about all that relates to the student. & 3.21 & 0.69 & 10 & Moderate \\
\hline & Total performance & 3.66 & 0.56 & 10 & Moderate \\
\hline
\end{tabular}

Table 9 shows that the mean of teacher and family domain (in terms of importance) were high and moderate. Item (9) obtained the first rank with a high degree of practice. It may be attributed to teacher adherence to the highest moral which is keeping secrets as a professional trust.

Item (8) obtained the last with a moderate degree of practice. It may be attributed to the overcrowding of the teacher's schedule, the high number of students in the class and the refusal of the school administration to open communication channels between teachers and families. 
To answer the question, what is the degree of practicing professional relationship between secondary school teacher and family from the perspective of school leaders in Riyadh? The mean and standard deviations were obtained as shown in Table 10.

Table 10 . The degree of practicing professional relationship between secondary school teacher and family

\begin{tabular}{|c|c|c|c|c|c|}
\hline No. & Item & Mean & $\begin{array}{l}\text { Standard } \\
\text { Deviation }\end{array}$ & Rank & $\begin{array}{c}\text { Practice } \\
\text { degree }\end{array}$ \\
\hline 6 & The teacher kindly listens to the family's observations about her performance. & 4.01 & 0.69 & 1 & High \\
\hline 4 & The family participates in decisions concerning their daughters. & 3.87 & 0.55 & 2 & High \\
\hline 2 & The teacher calls parents to participate in various events. & 3.83 & 0.57 & 3 & High \\
\hline 9 & The teacher keeps the secrets of parents. & 3.77 & 0.49 & 4 & High \\
\hline 8 & The teacher consults the family about all that relates to the student. & 3.71 & 0.56 & 5 & High \\
\hline 1 & The teacher is keen on enhancing trust between family and school. & 3.68 & 0.68 & 6 & High \\
\hline 7 & $\begin{array}{l}\text { The teacher cooperates with the family in solving the problems of their } \\
\text { daughters. }\end{array}$ & 3.59 & 0.63 & 7 & Moderate \\
\hline 10 & $\begin{array}{l}\text { The teacher is keen on benefiting from distinguished family members in } \\
\text { developing school work. }\end{array}$ & 3.54 & 0.51 & 8 & Moderate \\
\hline 5 & The teacher reports the family on the academic level of their daughters. & 3.40 & 0.70 & 9 & Moderate \\
\hline \multirow[t]{2}{*}{3} & $\begin{array}{l}\text { The teacher calls on parents to participate continuously and actively in the } \\
\text { activities of the school. }\end{array}$ & 3.17 & 0.64 & 10 & Moderate \\
\hline & Total performance & 3.64 & 0.54 & 10 & Moderate \\
\hline
\end{tabular}

Table 10 shows that the mean of teacher and family domain (in terms of practice) were high and moderate. Item (6) achieved the first rank with a high degree of practice. It may be attributed to the teacher awareness of the importance of developing school work and her moral duty. Item (3) got the last rank with a moderate degree of practice, due to lack of activities held by the school.

To answer the question, what are the statistically significant differences among respondents on the realization of the importance and practice of the teaching ethics according to the study variables? ANOVA and T-test calculated to the sample responses according to the study variables: school type, age, years of experience, and qualification.

Table 11. Statistical significance of the sample responses according to school type

\begin{tabular}{|c|c|c|c|c|c|c|}
\hline Domain & Variable & Mean & Standard Deviation & Freedom degree & (T) Value & Significance \\
\hline \multirow{2}{*}{ Teacher professional performance } & Public & 2.6495 & 1.10241 & 1127 & \multirow{2}{*}{4.84} & \multirow{2}{*}{0.187} \\
\hline & Private & 3.6146 & .68093 & 1127 & & \\
\hline \multirow{2}{*}{ Teacher and students } & Public & 2.6190 & 1.10962 & 1127 & \multirow{2}{*}{7.33} & \multirow{2}{*}{0.101} \\
\hline & Private & 3.9444 & .61551 & 1127 & & \\
\hline \multirow{2}{*}{ Teacher and Community } & Public & 2.5678 & .93646 & 1127 & \multirow{2}{*}{5.40} & \multirow{2}{*}{0.152} \\
\hline & Private & 3.5486 & .62205 & 1127 & & \\
\hline \multirow{2}{*}{ Teacher and school community } & Public & 2.5895 & 1.06456 & 1127 & \multirow{2}{*}{3.87} & \multirow{2}{*}{0.158} \\
\hline & Private & 3.4848 & .79189 & 1127 & & \\
\hline \multirow{2}{*}{ Teacher and family } & Public & 2.3667 & .85878 & 1127 & \multirow{2}{*}{1.68} & \multirow{2}{*}{0.403} \\
\hline & Private & 2.7417 & .76569 & 1127 & & \\
\hline
\end{tabular}

Table 11 shows that there are no statistically significant differences among the sample responses due to school type in all domains. It may be attributed to the importance of professional ethics to the teacher and the need to adhere to them because of their positive impact on the educational process and thus there is no effect of the school type on the commitment of teachers to professional ethics. This result is inconsistent with the results of the study by Covat (2002), Anangisye (2010), Das (2014), Gluchmanova (2015) and Tabachnick et al. (2016). 
Table 12. Statistical significance of the sample responses according to age

\begin{tabular}{|c|c|c|c|c|c|c|}
\hline Domain & $\begin{array}{l}\text { Source of } \\
\text { variation }\end{array}$ & $\begin{array}{l}\text { Sum of } \\
\text { Squares }\end{array}$ & $\begin{array}{l}\text { Degrees of } \\
\text { Freedom }\end{array}$ & $\begin{array}{c}\text { Mean } \\
\text { squares }\end{array}$ & $\begin{array}{c}\text { (P) } \\
\text { Value }\end{array}$ & Significance \\
\hline \multirow{3}{*}{$\begin{array}{c}\text { Teacher professional } \\
\text { performance }\end{array}$} & Among groups & 2.870 & 2 & 1.435 & \multirow{3}{*}{1.180} & \multirow{3}{*}{.308} \\
\hline & Within groups & 1368.358 & 1125 & 1.216 & & \\
\hline & Total & 1371.228 & 1127 & & & \\
\hline \multirow{3}{*}{ Teacher and students } & Among groups & 4.789 & 2 & 2.395 & \multirow{2}{*}{1.934} & \multirow{2}{*}{.145} \\
\hline & Within groups & 1393.095 & 1125 & 1.238 & & \\
\hline & Total & 1397.884 & 1127 & & & \\
\hline \multirow{3}{*}{ Teacher and community } & Among groups & 1.876 & 2 & .938 & \multirow{2}{*}{1.064} & \multirow{2}{*}{.345} \\
\hline & Within groups & 991.601 & 1125 & .881 & & \\
\hline & Total & 993.478 & 1127 & & & \\
\hline \multirow{3}{*}{ Teacher and school community } & Among groups & 2.711 & 2 & 1.355 & \multirow{2}{*}{1.194} & \multirow{2}{*}{.303} \\
\hline & Within groups & 1277.313 & 1125 & 1.135 & & \\
\hline & Total & 1280.024 & 1127 & & \multirow{4}{*}{.120} & \multirow{4}{*}{.887} \\
\hline \multirow{3}{*}{ Teacher and family } & Among groups & .177 & 2 & .088 & & \\
\hline & Within groups & 830.262 & 1125 & .738 & & \\
\hline & Total & 830.439 & 1127 & & & \\
\hline
\end{tabular}

Table 12 shows that there are no statistically significant differences among the sample responses due to age in all domains. It may be attributed to the provisions of the Code of Ethics of the teaching profession are taught at the university in the period of professional preparation and there is no relation to the variable of age by complying with the provisions of the Code of ethics.

Table 13. Statistical significance of the sample responses according to years of experience

\begin{tabular}{|c|c|c|c|c|c|c|}
\hline Domain & $\begin{array}{l}\text { Source of } \\
\text { variation }\end{array}$ & $\begin{array}{l}\text { Sum of } \\
\text { Squares }\end{array}$ & $\begin{array}{c}\text { Degrees of } \\
\text { Freedom } \\
\end{array}$ & $\begin{array}{c}\text { Mean } \\
\text { squares }\end{array}$ & $\begin{array}{c}(\mathrm{P}) \\
\text { Value }\end{array}$ & Significance \\
\hline \multirow{3}{*}{$\begin{array}{c}\text { Teacher professional } \\
\text { performance }\end{array}$} & Among groups & 8.521 & 2 & 4.261 & & \\
\hline & Within groups & 1362.707 & 1125 & 1.211 & 3.517 & .301 \\
\hline & Total & 1371.228 & 1127 & & & \\
\hline \multirow{3}{*}{ Teacher and students } & Among groups & 2.211 & 2 & 1.105 & & \\
\hline & Within groups & 1395.674 & 1125 & 1.241 & .891 & .411 \\
\hline & Total & 1397.884 & 1127 & & & \\
\hline \multirow{3}{*}{ Teacher and community } & Among groups & 2.195 & 2 & 1.097 & & \\
\hline & Within groups & 991.283 & 1125 & .881 & 1.245 & .288 \\
\hline & Total & 993.478 & 1127 & & & \\
\hline \multirow{3}{*}{ Teacher and school community } & Among groups & .997 & 2 & .499 & & \\
\hline & Within groups & 1279.027 & 1125 & 1.137 & .439 & .645 \\
\hline & Total & 1280.024 & 1127 & & & \\
\hline \multirow{3}{*}{ Teacher and family } & Among groups & .132 & 2 & .066 & & \\
\hline & Within groups & 830.307 & 1125 & .738 & .089 & .914 \\
\hline & Total & 830.439 & 1127 & & & \\
\hline
\end{tabular}

Table 13 shows that there are no statistically significant differences among the sample responses due to the years of experience in all domains. It may be explained by the relation between the teacher and school leaders and educational supervisors based on respect and mutual understanding regardless of the years of experience. They are perceived as partners in achieving the goals of education. Therefore, years of experience have no impact on the level of commitment to the ethics of the Teaching profession. This result is consistent with Das (2014) which showed that there is a positive relationship between the teaching experience and the professional ethics of female teachers. 
Table 14. Statistical significance of the sample responses according to qualification

\begin{tabular}{|c|c|c|c|c|c|c|}
\hline Domain & $\begin{array}{l}\text { Source of } \\
\text { variation }\end{array}$ & $\begin{array}{l}\text { Sum of } \\
\text { Squares }\end{array}$ & $\begin{array}{l}\text { Degrees of } \\
\text { Freedom }\end{array}$ & $\begin{array}{c}\text { Mean } \\
\text { squares }\end{array}$ & $\begin{array}{c}(\mathrm{P}) \\
\text { Value }\end{array}$ & Significance \\
\hline \multirow{3}{*}{$\begin{array}{c}\text { Teacher and professional } \\
\text { performance }\end{array}$} & Among groups & 3.047 & 2 & 1.523 & & \\
\hline & Within groups & 1368.181 & 1125 & 1.216 & 1.253 & .286 \\
\hline & Total & 1371.228 & 1127 & & & \\
\hline \multirow{3}{*}{ The teacher and students } & Among groups & 4.946 & 2 & 2.473 & & \\
\hline & Within groups & 1392.939 & 1125 & 1.238 & 1.997 & .136 \\
\hline & Total & 1397.884 & 1127 & & & \\
\hline \multirow{3}{*}{ Teacher and community } & Among groups & 2.171 & 2 & 1.086 & & \\
\hline & Within groups & 991.306 & 1125 & .881 & 1.232 & .292 \\
\hline & Total & 993.478 & 1127 & & & \\
\hline \multirow{3}{*}{ Teacher and school community } & Among groups & 4.319 & 2 & 2.159 & & \\
\hline & Within groups & 1275.705 & 1125 & 1.134 & 1.904 & .149 \\
\hline & Total & 1280.024 & 1127 & & & \\
\hline \multirow{3}{*}{ Teacher and family } & Among groups & .957 & 2 & .478 & & \\
\hline & Within groups & 829.482 & 1125 & .737 & .649 & .523 \\
\hline & Total & 830.439 & 1127 & & & \\
\hline
\end{tabular}

Table 14 shows that there are no statistically significant differences among the sample responses due to qualification in all domains. Teachers aspire to achieve excellence, creativity and uniqueness, regardless of their qualifications. This result is inconsistent with Boon (2011) which indicated absence of clear items related to education ethics during study.

\section{A Proposal for the Teaching Profession Ethics among Secondary School Teachers}

In light of the philosophy of the professional ethics of teaching, the current study attempts to present a proposal based on the study findings and the literature review.

\subsection{Philosophy}

Philosophy of the proposal is based on the vision of school leaders in Riyadh in relation to the Teaching ethics among secondary school teachers within a framework of integrated school representing a link between two educational stages. It is also based on the importance of professional ethics in promoting moral practices that should be effectively and positively reflected in the teaching methods and relations between the components of the educational process. The teacher should have positive attitudes toward the profession and commitment to the educational mission assigned to him/her toward students and community.

\section{Objectives}

1) Provide the teacher with a comprehensive set of values for the work and values under each dimension.

2) Activating the values as stated out in the Code of Ethics of the Teaching profession issued by the Ministry of Education in 2006.

3) Encouraging teacher to adopt ethical behavior in his life.

4) Improving the ethics of the Teaching profession among secondary school teachers.

5) Highlighting the importance of teacher training on professional ethics before work.

6) Providing communication channels with the parties concerned with educational and supervisory process such as the Ministry of Education, to establish effective cooperative practices to serve the educational process and to develop the teaching ethics.

\section{Requirements}

1) Affording the appropriate atmosphere for the improvement of the teaching profession ethics.

2) Involving individuals who are affected by the development in identifying objectives and implementation.

3) Serious follow-up to all phases of the development process.

4) Outstanding performance bonus.

5) Establish incentive systems for proposals for new developments and changes. 
6) Providing training programs about the ethics of the Teaching profession and working to minimize errors in the performance of the teacher.

\section{Mechanisms and Procedures}

1) Selecting teachers who have the ability and competence of using computer and web.

2) Selecting teachers with high professional ethics.

3) Following up their performance and development through the provision of several training courses in technology education.

4) Promoting respect for the teaching profession by providing good education for all.

5) Supporting efforts to promote democracy and human rights through education.

6) Teacher commitment to students, protecting their interests and protecting them from insult and physical abuse.

7) Teacher commitment to colleagues and keeping the confidentiality of their information.

8) Teacher commitment to the administration and the implementation of instructions.

\section{Implementation Challenges}

1) Deactivation of the punishment system.

2) Absence of the role model.

3) Absence of religious and national conscious and favoring personal interest.

4) Lack of mutual understanding between the official and staff.

5) Lack of the organizational awareness of the school.

These challenges can be overcome by adopting innovative philosophy that develops the mechanisms for implementing the above-mentioned vision.

\section{Conclusion}

The present study discussed the ethics of the teaching profession among secondary school teachers from school leaders' perspective in Riyadh. It covered the importance and practice of the ethics of the teaching profession among them, as well as the statistically significant differences among the participants on identifying the importance and practice of the ethics of the teaching profession according to the variables. Furthermore, it provided a proposal for the ethics of the teaching profession based on its results. The study covered some variables, e.g. school type, age, years of experience, and qualification. The results showed that the means were moderate and high in the domains of teacher professional performance, teacher and school community, as well as teacher and family. Additionally, there were no statistically significant differences in the participants' responses due to school type, age, years of experience, and qualification. Based on the results, the author made some recommendations that may significantly affect achieving the greatest benefit.

\section{Recommendations}

1) Developing moral constitution adopted by the Ministry of Education and the teachers before being appointed, as a reference for their ethical and professional behavior.

2) Enriching programs for qualifying and training teachers on the ethics of the teaching profession.

3) Establishing a website related to educational supervision and professional ethics that strengthens teacher commitment to ethics.

4) Reporting job performance evaluation templates to teachers.

5) Providing programs and training courses for fresh teachers about the professional ethics of teaching.

\section{References}

Abu Tabikh, H. N. (2007). The extent of school principals' commitment to the ethics of the teaching profession in the Governorate of Gaza from the perspective of teachers (Unpublished thesis). Islamic University of Gaza.

Afifi, S. M. (2005). Professional ethics of the teacher: A handbook to learn. Arab Organization for Administrative Development, Arab League.

Ajaji, A. A. (2012). The reality of implementing the teaching code of Ethics from the perspective of educational supervisors and principals of secondary schools in Riyadh (Unpublished thesis). Imam Muhammad bin 
Saud University, Saudi Arabia.

Al-Abboudi (2010). Evaluation of the performance of teachers of Islamic education in the light of the teaching code of ethics from the viewpoint of school principals and educational supervisors in Riyadh (Unpublished thesis). Islamic University in Madinah.

Alfalih, A. (2007). Riyadh's teacher attitudes towards and application of the importance of the code of professional teaching ethics in Saudi Arabia: A survey study (PhD thesis, American University in London, Britain).

Al-Ghamdi, H. (2006). Professional ethics among Muslim teachers and its impact on the moral education of the individual and society. Research presented to the 13th annual conference, held in the Saudi Society of Educational and Psychological Sciences (Justin), Faculty of Education, King Saud University, Riyadh.

Al-Ghamdi, H., \& Khalid, A. (2005). Ethics of the teaching profession and their promotion in the Saudi educational system. Paper presented at the Symposium of Ethics of Work in the Public and Private Sectors, Institute of Public Administration, Riyadh.

Al-Hujilan, N. (2007). The need for a code of ethics for the teaching profession. Al-Riyadh Newspaper, 14080. Retrieved from http://www.alriyadh.com/215394

Al-khamees, M. I. A. (2013). The degree of high school principals' commitment in Kuwait to the ethics of the school management profession and its relation to the organizational loyalty of the teachers from their perspective (Unpublished thesis). Middle East University. Amman: Jordan.

Al-Luqmani, A. S. (2007). Secondary school teachers' commitment to the ethics of the teaching profession from supervisors and principals perspective of secondary schools in Makkah (Unpublished thesis). Umm Al Qura University, Saudi Arabia.

Al-Mafdi, S. (2004). Preparation of the teacher of Islamic education in light of the immediate and future needs of high school students. A research presented to the 16th scientific conference of the Egyptian Society for Curriculum and Teaching Methods, entitled (teacher formation "preparation and training"). Retrieved from https://goo.gl/3yH89m

Al-Qahtani, H. N. (2013). The degree of commitment of the principals of public education schools in the governorate of Khamis Mushait to the teaching code of ethics from teachers' perspective (Unpublished thesis). Umm Al Qura University, Saudi Arabia.

Al-Qarni, A. A. G. (2008). Work values contained in the Teaching code of Ethics from the Islamic Perspective and the Mechanism for activating it among teachers (Unpublished thesis). Umm Al Qura University, Saudi Arabia.

Al-Roumi, S. S. (2009). Degree of educational supervisors' commitment in the governorates of Gaza to the ethics of the profession from their perspective (Unpublished thesis). Islamic University, Gaza.

Al-Zubi, R. (2013). The degree of cooperating teachers' commitment to the ethics of the Teaching profession from the perspective of female trainees at Al-Bayt University. Al-Manara Magazine, 19(3), 441-476.

Anangisye, W. (2010). Promoting teacher ethics in colleges of teacher education in Tanzania: practices and challenges. AJOTE, 1(1), 64-77.

Boon, H. J. (2011). Raising the Bar: The teaching profession ethics for Quality Teachers. Australian Journal of Teacher Education, 36(7). https://doi.org/10.14221/ajte.2011v36n7.2

Capli, F. A. (2015). The role of school principals in promoting teaching ethics among teachers from principals and teachers perspective in Makkah public schools (Unpublished thesis). Umm Al Qura University, Saudi Arabia.

Cevat, C. (2002). Teachers' organizational commitment in educational organizations. National forum Journals, 11(3), 1-10.

Das, S. (2014). Professional ethics grow with teaching experience: A research of women teachers in higher education institutions in Punjab. European Academic Research, II(4).

Deshach, N. (2014). The Profession of Education, Ethics and the Role of Teacher. Journal of Research and Humanities, 8, 218-237.

Forster, D. J. (2012). Codes of Ethics in Australian Education: Towards a National Perspective. Australian Journal of Teacher Education, 37(9). https://doi.org/10.14221/ajte.2012v37n9.4 
Ibrahim. (2012). Proposed code of ethics for the teaching profession in Saudi Arabia (Unpublished MA thesis). Saudi Arabia

Jaballa, M. (2006). Ethics of the teaching profession in light of future challenges. Paper presented at the 13th Annual Meeting "Teacher Preparation and Development in light of the Contemporary Challenges", the Saudi Association for Education \& Psychology \& College of Education, King Saud University, Riyadh.

Kendrick, E. (2006). Ethics at work. USA: The Georgia Department of Technical and Adult Education.

Mansour, H. K., \& Talafh, H. A. (2009). The System of Ethical Values Included in the Books of Islamic Education for the Basic Stage in Jordan. Journal of Educational Sciences Studies, 39(1), 46-70.

Ministry of Education. (2006). Code of ethics of Ethics of the Teaching profession, E1, Educational Development. Saudi Arabia.

Murtaja, A. M. M. (2004). The extent of practicing ethics among secondary school students from their teachers' perspective in Gaza (MA Thesis, Al-Azhar University, Gaza).

Nadia. (2015). Professional Ethics of Teachers in Educational Institutions Nanigopal Malo. International Research Journal of Interdisciplinary \& Multidisciplinary Studies (IRJIMS), I(VI), 94-98.

Nazzal, M. (2001). Ethics of the teaching profession in the light of Islamic thought and the extent of teachers' commitment from principals and supervisors perspective in Palestine (Unpublished thesis). Al-Quds University, Palestine.

Tabachnick, B. G., Keith-Spiegel, P., \& Pope, K. S. (2016). Ethics of teaching: Beliefs and behaviors of $\begin{array}{llll}\text { psychologists as educators. American Psychologist, 46(5), 506-515. } & \text {. }\end{array}$ https://doi.org/10.1037/0003-066X.46.5.506

\section{Copyrights}

Copyright for this article is retained by the author(s), with first publication rights granted to the journal.

This is an open-access article distributed under the terms and conditions of the Creative Commons Attribution license (http://creativecommons.org/licenses/by/4.0/). 